\title{
Exercise training and post-operative prognosis after coronary intervention
}

\author{
Gennaro Pagano ${ }^{1 *}$, Dario Leosco ${ }^{1}$, Nicola Ferrara ${ }^{1,2}$, Nicola Rocco $^{3}$, Corrado Rispoli $^{4}$, Loredana lannone ${ }^{5}$, \\ Serena Testa ${ }^{4}$, Antonello Accurso ${ }^{6}$, Rita Compagna ${ }^{6}$, Bruno Amato ${ }^{6}$ \\ From 26th National Congress of the Italian Society of Geriatric Surgery \\ Naples, Italy. 19-22 June 2013
}

Aging is worldwide recognized as a dominant risk factor for most forms of cardiovascular disease [1-3]. However, mechanisms by which it exerts its role and determines poor outcome have been only partially clarified. Numerous evidence indicate that aging is associated with alteration of several mechanisms whose integrity confers protective action on the heart and vasculature [5-9]. Autonomic status derangement, diminished efficacy of ischemic preconditioning, impaired angiogenic responses after ischemic injury, increased oxidative stress, and abnormal left ventricular remodelling after myocardial infarction are all putative mechanisms potentially involved in the vulnerability of cardiovascular system occurring with aging. Interestingly, many of the alterations that take place in the aged heart and vasculature are very similar to those observed in pathologic conditions, such as heart failure (HF), and, most importantly, are at least in part revertible. Exercise training plays a pivotal role in primary and secondary prevention of cardiovascular disease, in counteracting the age-related deterioration of some mechanisms that are crucially involved in the homeostasis of cardiovascular system and that may condition the outcome of cardiovascular disease in the elderly. Moreover, it is associated to reduction of the post-operative atrial fibrillation with reduction of the number of prescribed drugs [10]. Preconditioning represent the strongest form of in vivo protection against myocardial ischemic injury, consisting in brief episodes of myocardial ischemia able to reduce cellular damage subsequent to a more prolonged ischemic injury. Remote preconditioning is the phenomenon by which ischemia in one region of the heart causes protection in a remote region of the heart itself or of another organ, thus suggesting that

\footnotetext{
* Correspondence: gennaropagano85@hotmail.com

'Department of Translational Medical Sciences, Federico II University of

Naples, Naples, Italy

Full list of author information is available at the end of the article
}

circulating factors or a neural reflex triggers protection in the remote region. Aging is associated with higher rates of morbidity after coronary intervention and a progressive loss in efficacy of ischemic preconditioning with age has been indicated as a potential mechanism explaining the worse prognosis in the elderly. A diminished norepinephrine release in response to transient ischemic stress has been indicated having role in the loss of preconditioning protection occurring with age. Preinfarction angina is considered one of the strongest clinical equivalent of ischemic preconditioning being associated with both reduction in infarct size and prevention of left ventricular dysfunction. Evidences demonstrate the loss of the protective effect of preinfarction angina with age, resulting in a no more protective effect on both early and late mortality in the elderly after acute cardiac events.

In adult and elderly humans, high levels of physical activity preserve the protective role of preinfarction angina against in-hospital mortality and cardiogenic shock after myocardial infarction. More recent data indicate that higher levels of physical activity performed before primary coronary angioplasty may independently predict the reduction of early and late cardiac mortality in older infarcted patients [11]. Accordingly, it has been reported a robust association between physical activity habits of elderly participants prior to coronary artery bypass grafting and survival free from both all-cause and cardiac death, [12]. Interestingly, in these studies, the greatest benefits of exercise on survival were observed in the more sedentary patient groups, thus strongly supporting the importance of implementation of physical activity levels in the elderly also as secondary prevention strategy.

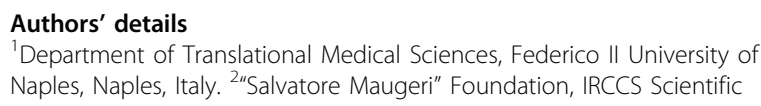


Institute of Telese Terme, Benevento, Italy. ${ }^{3}$ Department of Biomedical, Surgical and Dental Sciences, University of Milan, Milan, Italy. ${ }^{4}$ Department of General Surgery - ASL NA1, Cardinale Ascalesi Hospital, Naples, Italy. ${ }^{5}$ Department of General Surgery, Fatebenefratelli Hospital, Benevento, Italy. ${ }^{6}$ Department of General, Geriatric, Oncologic Surgery and Advanced Technologies, Federico II University of Naples, Naples, Italy.

Published: 16 September 2013

\section{References}

1. Rengo F, Parisi V, Rengo G, Femminella GD, Rengo C, Zincarelli C, Pagano G, Festa G, De Lucia C, Leosco D: Instruments for geriatric assessment: new multidimensional assessment approaches. JOURNAL OF NEPHROLOGY 2012, 25:73-78, ISSN: 1121-8428, doi: 10.5301/jn.5000164.

2. Pilotto A, Addante F, Franceschi M, Leandro G, Rengo G, D'Ambrosio P, Longo MG, Rengo F, Pellegrini F, Dallapiccola B, Ferrucci L: A Multidimensional Prognostic Index (MPI) based on a Comprehensive Geriatric Assessment Predicts Short-Term Mortality in Older Patients with Heart Failure. Circulation: Heart Failiure 2010, 3:14-20.

3. Rengo F, Leosco D, lacovoni A, Rengo G, Golino L, Borgia F, De Lisa G, Beneduce F, Senni M: Epidemiology and risk factors for heart failure in the elderly. Italian heart journal: official journal of the Italian Federation of Cardiology 2004, 5(Suppl 10):9S-16S.

4. Paolillo S, Rengo G, Pagano G, Pellegrino T, Savarese G, Femminella GD, Tuccillo, Boemio A, Attena E, Formisano R, Petraglia L, Scopacasa F, Galasso G, Leosco D, Trimarco B, Cuocolo A, Perrone-Filardi P: Impact of Diabetes Mellitus on Cardiac Sympathetic Innervation in Patients With Heart Failure. A lodine-123 meta-iodobenzylguanidine (I123MIBG) Scintigraphic Study. Diabetes Care 2013.

5. Rengo G, Lymperopoulos A, Zincarelli C, Femminella Gd, Liccardo D, Pagano G, de Lucia C, Cannavo A, Gargiulo P, Ferrara N, Perrone Filardi P, Koch Wj, Leosco D: Blockade of beta-adrenoceptors restores the GRK2mediated adrenal alpha(2) -adrenoceptor-catecholamine production axis in heart failure. BRITISH JOURNAL OF PHARMACOLOGY 2012, 166:2430-2440, ISSN: 1476-5381, doi: 10.1111/j.1476-5381.2012.01972.x.

6. Rengo G, Zincarelli C, Femminella GD, Liccardo D, Pagano G, de Lucia C, Altobelli GG, Cimini V, Ruggiero D, Perrone-Filardi P, Gao E, Ferrara N, Lymperopoulos A, Koch WJ, Leosco D: Myocardial beta(2) -adrenoceptor gene delivery promotes coordinated cardiac adaptive remodelling and angiogenesis in heart failure. BRITISH JOURNAL OF PHARMACOLOGY 2012, 166:2348-2361, ISSN: 1476-5381, doi: 10.1111/j.1476-5381.2012.01954.x.

7. Rengo G, Perrone-Filardi P, Femminella GD, Liccardo D, Zincarelli C, de Lucia C, Pagano G, Marsico F, Lymperopoulos A, Leosco D: Targeting the beta-adrenergic receptor system through $\mathrm{G}$-protein-coupled receptor kinase 2: a new paradigm for therapy and prognostic evaluation in heart failure: from bench to bedside. CIRCULATION. HEART FAILURE 2012, 5:385-391, ISSN: 1941-3289, doi: 10.1161/CIRCHEARTFAILURE.112.966895.

8. Giugliano G, Sannino A, Brevetti L, Perrino C, Schiattarella G, Franzone A, Serino F, Ferrone M, Scudiero F, Carbone A, De Paulis M, Izzo R, Amato B, Bruno Trimarco B, Esposito G: Ankle/brachial index to everyone. BMC Surgery 2012, 12(Suppl 1):S18, doi:10.1186/1471-2482-12-S1-S18.

9. Leosco D, Rengo G, laccarino G, Golino L, Marchese M, Fortunato F, Zincarelli C, Sanzari E, Ciccarelli M, Galasso G, Altobelli GG, Conti V, Matrone G, Cimini V, Ferrara N, Filippelli A, Koch WJ, Rengo F: Exercise promotes angiogenesis and improves $\beta$-adrenergic receptor signalling in the post-ischaemic failing rat heart. Cardiovascular Research 2008, 30(3).

10. Rengo G, Pagano G, Squizzato A, Moja L, Femminella GD, de Lucia C, Komici K, Parisi V, Savarese G, Ferrara N, Perrone-Filardi P, Leosco D: Oral anticoagulation therapy in heart failure patients in sinus rhythm: a systematic review and meta-analysis. PloS One 2013, 8(1):e52952, doi:10.1371/journal.pone.0052952.

11. Rengo G, Galasso G, Piscione F, et al: An active lifestyle improves outcome of primary angioplasty in elderly patients with acute myocardial infarction. Am Heart J 2007, 154:352-60.

12. Rengo G, Galasso G, Vitale DF, et al: An active lifestyle prior to coronary surgery is associated with improved survival in elderly patients. $J$ Gerontol A Biol Sci Med Sci 2010, 65:758-63.

doi:10.1186/1471-2482-13-S1-A33

Cite this article as: Pagano et al:: Exercise training and post-operative prognosis after coronary intervention. BMC Surgery 2013 13(Suppl 1):A33.

\section{Submit your next manuscript to BioMed Central and take full advantage of:}

- Convenient online submission

- Thorough peer review

- No space constraints or color figure charges

- Immediate publication on acceptance

- Inclusion in PubMed, CAS, Scopus and Google Scholar

- Research which is freely available for redistribution 